\title{
Gray-bellied Hawk (Accipiter poliogaster) Observed Feeding on a Tinamou in Yasuni Biosphere Reserve, Ecuador
}

\author{
Author(s): Kimberley MelnykRudy A. GelisWilliam A. HopkinsFernando \\ Vacalgnacio T. Moore
}

Source: Journal of Raptor Research, 47(3):330-332.

Published By: The Raptor Research Foundation

DOI: http://dx.doi.org/10.3356/JRR-12-00015.1

URL: http://www.bioone.org/doi/full/10.3356/JRR-12-00015.1

BioOne (www.bioone.org) is a nonprofit, online aggregation of core research in the biological, ecological, and environmental sciences. BioOne provides a sustainable online platform for over 170 journals and books published by nonprofit societies, associations, museums, institutions, and presses.

Your use of this PDF, the BioOne Web site, and all posted and associated content indicates your acceptance of BioOne's Terms of Use, available at www.bioone.org/ page/terms of use.

Usage of BioOne content is strictly limited to personal, educational, and noncommercial use. Commercial inquiries or rights and permissions requests should be directed to the individual publisher as copyright holder. 


\section{Gray-Bellied Hawk (ACCIPITER POLIOGASTER) ObSERVEd FeEding ON a Tinamou in YASUNI BIOSPHERE RESERVE, ECUADOR}

KeY WoRDS: Gray-bellied Hawk; Accipiter poliogaster; diet; Ecuador, tinamou.

The Gray-bellied Hawk (Accipiter poliogaster) is one of the least studied birds of prey in the neotropics. Its geographical range in South America is from northern Colombia, east to southern Venezuela and the Guianas, south to northeastern Ecuador, eastern Peru, Amazonian and southeastern Brazil, northern Bolivia, southeastern Paraguay and northeastern Argentina (Jenkinson and Tuttle 1976, Ridgely and Greenfield 2001, Thiollay 2007, Global Raptor Information Network 2012). Despite a lack of information regarding its movements, the Gray-bellied Hawk is thought to be a permanent resident in Ecuador due to year-round sightings of the species (Ridgely and Greenfield 2001, Global Raptor Information Network 2012).

In Ecuador, the Gray-bellied Hawk is very rare (but not considered endangered) and is confined to the humid eastern lowland forests and forest edges. Published sightings in Ecuador are from nine lowland localities and only two specimens have been collected (Gurney 1881, Ridgely and Greenfield 2001, Buitrón-Jurado 2011, Global Raptor Information Network 2012). Most reports are of birds found within primary forest, although Buitrón-Jurado (2011) recently observed one in secondary forest along the Rio Villano in the Pastaza province. There is no information on the breeding and nesting behavior of the Graybellied Hawk, but there has been speculation that an account by De Vries and Melo (2000) on the nesting behavior of a pair of Slaty-backed Forest-Falcons (Micrastur mirandollei) was actually based on a misidentification and the pair may have been Gray-bellied Hawks or some other Accipiter species (Thorstrom 2002).

The adult Gray-bellied Hawk is one of the larger Accipiter species, ranging from $38-51 \mathrm{~cm}$ in overall body length, with females being larger than males. They are slate gray on the head and back, with the crown slightly darker, almost black. The tail is gray with three dirty white/light gray bands and a white tip at the end of the tail. The underside of the bird, starting from the chin, is white, sometimes fading into buff. A defining characteristic of the Gray-bellied Hawk is its "capped" or "hooded" appearance caused by the gray coloration of the head running halfway 


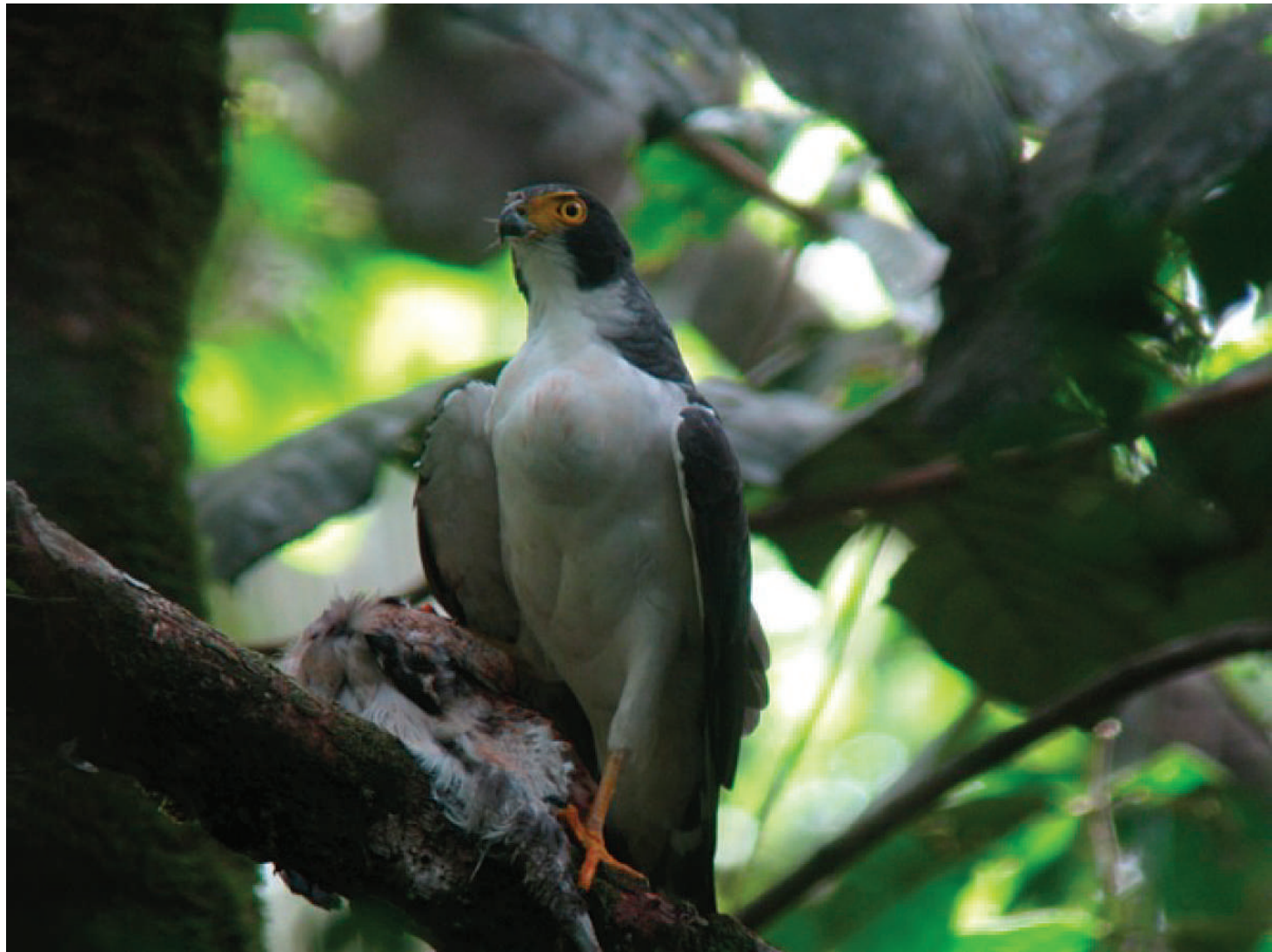

Figure 1. Digiscope image of a Gray-bellied Hawk with tinamou prey in talons at Shiripuno Amazon Lodge. The sighting occurred around $1100 \mathrm{H}$ on 20 May 2012.

down the neck before abruptly turning white. The iris, cere, orbital skin, and legs are all yellow (Ridgley and Greenfield 2001). The bill and head are described as heavy, and the wings, legs, and tail are all relatively short (Ferguson-Lees and Christie 2001).

On 20 May 2012, we observed a Gray-bellied Hawk while hiking through the primary forest on the Skutch trail at Shiripuno Amazon Lodge. The lodge is located along the Shiripuno River in the Yasuni Biosphere Reserve within the Orellana province of Ecuador $\left(1^{\circ} 6.28^{\prime} \mathrm{S}, 76^{\circ} 43.89^{\prime} \mathrm{W}\right.$; $300 \mathrm{~m}$ asl). The sighting occurred at approximately $1100 \mathrm{H}$ and lasted approximately $20 \mathrm{~min}$. We first spotted the hawk flapping its dark wings as it landed on a branch about $15 \mathrm{~m}$ away from us, off the side of the trail, at an approximate height of $8 \mathrm{~m}$. The hawk was feeding on an unknown species of medium-sized tinamou that it held in its talons. We observed the hawk feeding on the tinamou and a full crop was also evident. Based on the tinamou's size relative to the Gray-bellied Hawk, grayish leg color, the habitat, and the geographical ranges of local species, we have limited the possible species of tinamou to either a Great Tinamou (Tinamus major) or a White-throated Tinamou
(Tinamus guttatus). We recorded 1:37 min of video (which can be viewed at http://youtu.be/m_HiK7Ly7PA) and photographs, by digiscoping with a Canon Powershot camera through a 20X Swarovski spotting scope (Fig. 1), before it flew away with the tinamou in its talons.

The Gray-bellied Hawk is often confused with the Slatybacked Forest-Falcon (Thorstrom 2002). Based on our photos and video, we noted a decidedly Accipiter-shaped head (as opposed to the blocky-headed Micrastur mirandollei), darker coloration on the head instead of a uniform gray color, plus the distinctly hooded appearance (Fig. 1). Together these characters make identification definitive.

Our fortuitous encounter added to the little that is known about the feeding behavior and diet of the Graybellied Hawk. These hawks are thought to be still hunters, not known for actively hunting by soaring, but rather perching in the open canopy waiting for prey to pass by the perch (Ferguson-Lees and Christie 2001, Ridgely and Greenfield 2001). This species has been observed in Peru diving into the center of a mixed species flock of birds (Hilty 2003), and has been observed taking small passerines (Ferguson-Lees and Christie 2001). There was also 
one reported case in Panará, Brazil, in which a dead Graybellied Hawk was collected after it had smashed into a window while chasing an unidentified Columbidae, there was no food found in the digestive tract of the dead individual (Lanzer et al. 2009). Ferguson-Lees and Christie (2001) speculated that in addition to preying upon small birds, the Gray-bellied Hawk might be a semi-specialized hunter of arboreal lizards, tree frogs, and large insects. Our observation of this species eating and carrying away a medium-sized tinamou adds to our knowledge of the Graybellied Hawk's diet, though more information is needed on the basic biology of this species across its range.

We acknowledge all the members of the Virginia Tech study abroad class that visited Shiripuno during May 2012. We also thank the local guides and staff who enabled us to have the opportunity to observe this bird at Shiripuno Amazon Lodge.-Kimberley Melnyk, Department of Biological Sciences, Virginia Tech, Blacksburg, VA 24061 U.S.A.; Rudy A. Gelis, Yanayacu Biological Station and Center for Creative Studies, Cosanga, Ecuador; William A. Hopkins, Department of Fish and Wildlife Conservation, Virginia Tech, Blacksburg, VA 24061 U.S.A.; Fernando Vaca, Shiripuno Amazon Lodge, Pastaza and Orellana Provinces, Ecuador; and Ignacio T. Moore (e-mail address: itmoore@vt.edu), Department of Biological Sciences, Virginia Tech, Blacksburg, VA 24061 U.S.A.

\section{Literature Cited}

Buitrón-JuRAdo, G. 2011. Interesting distributional record of Amazonian birds from Pastaza, Ecuador. Bulletin of the British Ornithologists' Club 131:241-248.
DE VRIES, T. AND C. MeLo. 2000. First nesting record of a Slaty-backed Forest-Falcon (Micrastur mirandollei) in Yasuni National Park, Ecuadorian Amazon. Journal of Raptor Research 34:148-150.

Ferguson-Lees, J. And D.A. Christie. 2001. Raptors of the world. Houghton Mifflin, Boston, MA U.S.A.

GLOBAL RAPTOR INFORMATION NETWORK. 2012. Species account: Gray-bellied Hawk Accipiter poliogaster. http:// www/globalraptors.org (last accessed 8 June 2012).

GuRNEY, J.H. 1881. Notes on some hawks of the subgenera Cooperastur and Urospizias. Ibis 23:258-267.

Hilty, S.L. 2003. Birds of Venezuela, Second Ed. Princeton University Press, Princeton, NJ U.S.A.

Jenkinson, M.A. AND M.D. TutTLE. 1976. Accipiter poliogaster from Peru, and remarks on two collecting localities named "Sarayacu." Auk 93:187-189.

Lanzer, M., M.A.V. VAllejos, AND M. Aurelio-Silva. 2009. First documented record of Accipiter poliogaster (Temminck, 1824) in the state of Panará, southern Brazil (Falconiformes, Accipitridae). Revista Brasileira de Ormitologia 17:137-138.

Ridgely, R.S. And P.J. GReEnfield. 2001. The birds of Ecuador. Comstock Publ., Ithaca, NY U.S.A.

Thiollay, J.-M. 2007. Raptor communities in French Guiana: distribution, habitat selection, and conservation. Journal of Raptor Research 41:90-105.

Thorstrom, R. 2002. Comments on the first nesting record of the nest of a Slaty-backed Forest-Falcon (Micrastur mirandollei) in the Ecuadorian Amazon. Journal of Raptor Research 36:335-336.

Received 18 September 2012; accepted 12 December 2012 